\title{
Synthetic Black Water Treatment by Aeroponic Cultivation of Water Spinach: Effect of the Pump Run Time
}

\author{
Benjian Sun ${ }^{1,2}$, Jiyong Cen ${ }^{1,2}$, Zhan Jin", , Jin Zhou ${ }^{1,2}$, Xianfeng Huang1,2, \\ Hainan Kong ${ }^{3}$, Min Zhao', ${ }^{1,}$, Xiangyong Zheng1, 2* \\ ${ }^{1}$ School of Life and Environmental Science, Wenzhou University, Wenzhou325027, Zhejiang, China \\ ${ }^{2}$ Urban Water Pollution Ecological Treatment Technology Zhejiang Engineering Laboratory, \\ Wenzhou325027, Zhejiang, China \\ ${ }^{3}$ School of Environmental Science and Engineering, Shanghai Jiao Tong University, Shanghai, China
}

Received: 14 December 2019

Accepted: 31 July 2020

\begin{abstract}
In this study, we report the treatment of simulated black water using a decentralised aeroponic system for the cultivation of water spinach. The effect of the pump run time on the treatment efficiency of black water at low temperature $\left(15^{\circ} \mathrm{C} \pm 5^{\circ} \mathrm{C}\right)$ in winter was systematically investigated. The results show that aeroponic cultivation process yields average chemical oxygen demand (COD) removal of $90.04 \%$, ammonia nitrogen $\left(\mathrm{NH}_{4}^{+}-\mathrm{N}\right)$ reduction of $35.02 \%$, total nitrogen (TN) abatement of $28.14 \%$, and total phosphorus (TP) elimination of $14.71 \%$. The increase in the pump run time from stop time (min) to spray time (s) ration of 45:30 (QW3) to 15:30 (QW1) significantly promotes the efficiency of the COD, $\mathrm{NH}_{4}^{+}-\mathrm{N}, \mathrm{TN}$, and TP removals. The sequence of the removal efficiency is as follows: QW1 (15:30) $>$ QW2 (30:30)> QW3 (45:30). The higher efficiency of the COD and $\mathrm{NH}_{4}^{+}-\mathrm{N}$ removals in QW1 is due to the enhanced action of aerobic microorganisms because of the increased amount of dissolved oxygen. We believe that this study provides a simple and potential option for decentralised sewage.
\end{abstract}

Keywords: aeroponic cultivation system, black water, low temperature, pump run time, water spinach

\section{Introduction}

Water shortages significantly affect the livelihoods of human beings. China is one of 13 countries with severe water shortages [1]. Recently, the urbanisation in China has accelerated, resulting in the direct

*e-mail: 00121051@wzu.edu.cn

discharge of considerable amounts of industrial and domestic sewage into surface- and ground-water. This causes an enormous economic loss and waste of resources, threatens the human health, and degrades the environment [2]. Thus, the problems associated with the water conservation and utilisation of wastewater must be solved [3].

Currently, domestic wastewater is treated using end collection and subsequent centralised treatment 
in most cities in China, which is expensive due to the high costs associated with the construction and maintenance of the collection network. This treatment method leads to excessive amounts of sludge and the recovery of nitrogen, phosphorus, and recycled water is difficult. The application of the centralised process in rural areas is limited because of the complex terrain and low financial status. An alternative strategy for the treatment of rural wastewater is decentralised wastewater treatment, which has many benefits, for example, there is no need for a large-scale pipe network, the construction costs are low, the implementation and operation are convenient, and the recovery and utilisation of water are simple [4].

Approximately $90 \%$ of the total nitrogen (TN), $50 \%$ of the chemical oxygen demand (COD), and $80 \%$ of the total phosphorus (TP) in the domestic wastewater originate from toilet-flushing sewage (black water), accounting for approximately one-third of the total water [5]. Therefore, the separation of the water containing feces and urine (black water) from other drainage water (grey water) and the application of decentralised ecological black water treatment technologies, such as constructed wetlands, drip irrigation, and aquatic plant remediation technologies, would greatly reduce the cost of the sewage treatment and improve the treatment efficiency. Moreover, those processes favour the recirculation and reuse of black water for agricultural production and reduce the physical footprint of sewage treatment facilities, which has many advantages including low cost and energy consumption, high efficiency, smaller disturbance of the environment, no secondary pollution, and circulation of nutrients such as nitrogen and phosphorus [6-10].

Aeroponic cultivation is a new type of soilless culture technology. The nutrient solution is atomized to meet the water and fertilizer demand for plant growth. It does not require an implant matrix; therefore, the cultivation facility is suitable for roofs or balconies of buildings due to its light weight. In addition, aeroponic cultivation has strong reaeration ability because of atomization of the solution. At present, this technology is mostly used for agricultural production to enhance crop yields and reduce the water and fertiliser volumes [11]. However, little research has been carried out on the purification and reuse of black water.

The pump run time is a key parameter in aeroponic cultivation. The effect of the pump run time on the treatment of black water was investigated in this study. The efficiencies of the removals of COD, $\mathrm{NH}_{4}^{+}-\mathrm{N}, \mathrm{TN}$, and TP and transformation of $\mathrm{NO}_{3}^{-}-\mathrm{N}$ and $\mathrm{NO}_{2}^{-}-\mathrm{N}$ were analysed to interpret the process. The variance analyses of the water quality indexes were compared using SPSS 14.0. Finally, the biomass obtained from the aeroponic cultivation system was analysed.
Table 1. Water quality of the simulated black water (SBW) and tested black water (TBW).

\begin{tabular}{|c|c|c|}
\hline Component & SBW $(\mathrm{mg} / \mathrm{L})$ & TBW $(\mathrm{mg} / \mathrm{L})$ \\
\hline $\mathrm{COD}$ & 200 & $183-237$ \\
\hline $\mathrm{NH}_{4}^{+}-\mathrm{N}$ & 29.0 & $29.57-34.01$ \\
\hline $\mathrm{TN}$ & 30.0 & $30.89-36.54$ \\
\hline $\mathrm{TP}$ & 18.2 & $13.57-19.59$ \\
\hline $\mathrm{SO}_{4}^{2-}$ & 32 & -- \\
\hline $\mathrm{Ca}^{2+}$ & 10.8 & - \\
\hline
\end{tabular}

\section{Material and Methods}

\section{Test Plant}

A test plant, water spinach (Ipomoea aquatica), was purchased from the market. All old leaves were removed and a plant length of $\sim 10 \mathrm{~cm}$ was retained prior to the experiment to ensure the plant survival and growth.

\section{Test Black Water}

The COD and total nitrogen concentration of black water are very high, with values reaching 1000 and $300 \mathrm{mg} / \mathrm{L}$, respectively [11]. Real black water with high COD and ammonia nitrogen content is disadvantageous for the survival of the test plants in the aerosol system [5, 12-14]. Therefore, synthetic black water comparable to five-fold diluted black water was used for the experiments. The water quality is shown in Table 1 and the composition is illustrated in Tables S1 and S2.

\section{Aeroponic Cultivation Devices and Experimental Procedures}

The aeroponic experiments were carried out in polypropylene $(\mathrm{PP})$ plastic devices $(0.41 \times 0.2 \times 0.33 \mathrm{~m})$, with 15 plants in an array (5 columns and 3 rows; Fig. 1). The planting holes were evenly arranged in the lid of the box containing four atomising nozzles. Four water spinach plants were planted in each basket (the planting density of the water spinach is 732 trees $/ \mathrm{m}^{2}$ ) and then fixed and packed with cylindrical activated carbon. The roots of the plants were not submerged in black water but suspended above it such that the cells of the roots were not affected by sewage, even if the BOD or COD were high. The sewage volume of each device was maintained at $11 \mathrm{~L}$, including $10 \mathrm{~L}$ fresh prepared black water and $1 \mathrm{~L}$ sludge-rich stock solution. The test sewage was atomised and sprayed regularly with a booster pump (Deng Yuan TYP2500) controlled by a timing controller. Based on the ratio of the stop time ( $\mathrm{min})$ to the spray time (s), the run time was set as follows: spraying for $30 \mathrm{~s}$ every $15 \min (15: 30), 30 \mathrm{~min}$ (30:30), and $45 \mathrm{~min}(45: 30)$. 
Three parallel devices were included in this test, that is, QW1, QW2, and QW3, and continuously worked for 24 hours per day in interval of 15,30 and $45 \mathrm{~min}$, respectively. The average evaporation capacities of black water in QW1, QW2, and QW3 were 150, 180, and $350 \mathrm{ml} / 24 \mathrm{~h}$, respectively. The proportion of the evaporated water was less than $3.5 \%$; therefore, the effect of evaporation induced by spraying on the test results was negligible. The devices started working at the same time and with the same influent quality. Every device contained a booster pump and timing controller; thus, there was no influence or interference between the devices.

After the aeroponic cultivation devices were prepared, the water spinach was allowed to adjust to the new environment for at least a week. The adjustment stage lasted from 25-31 October and the measurements began on 1 November. Measurements of the COD, $\mathrm{NH}_{4}^{+}-\mathrm{N}, \mathrm{TN}, \mathrm{TP}, \mathrm{NO}_{3}^{-}-\mathrm{N}, \mathrm{NO}_{2}^{-}-\mathrm{N}$, dissolved oxygen (DO), water temperature, and $\mathrm{pH}$ were performed twice a week. Every parameter was measured 15 times. On the day before testing, the black water stored for 24 hours in the devices was poured out, leaving behind $\sim 1$ L of stock solution containing a large amount of activated sludge. Subsequently, 10 L new synthetic black water was added to the devices. At the same time, raw synthetic black water was used to determine the initial concentrations of pollutants and other indicators. After 24 hours, the treated black water was retrieved to analyse the same indicators. Subsequently,
$200 \mathrm{ml}$ black water from the septic tank was added to the devices every day during the test interval to ensure the biological activity of the microorganisms inside the devices. The addition of real black water led to a small variation in the water quality of the actual tested black water, as shown in Table 1.

\section{Methods}

The detection methods used for various parameters are as follows. The COD was measured using the $\mathrm{HACH}$ reagent digestion method and a HACH DR3900 bench-top spectrophotometer. The $\mathrm{NH}_{4}^{+}-\mathrm{N}$ was detected using Nessler's reagent spectrophotometry. The TN was analysed using alkaline potassium persulfate digestion spectrophotometry. The TP was determined with potassium persulfate digestion spectrophotometry. The $\mathrm{NO}_{3}^{-}-\mathrm{N}$ and $\mathrm{NO}_{2}^{-}-\mathrm{N}$ were separately measured using ultraviolet (UV) spectrophotometry and N-(1-naphthyl)ethylenediamine spectrophotometry. The DO, water temperature, and $\mathrm{pH}$ were measured with a $\mathrm{HACH}$ $\mathrm{DO} / \mathrm{pH}$ meter.

At the end of the experiment, the water spinach above the surface of the filler was collected, dried in an oven at $105^{\circ} \mathrm{C}$, until a constant weight was obtained, and weighed with an electronic balance. The variance analysis of the experimental results and comparison between different samples were performed using SPSS 14.0.
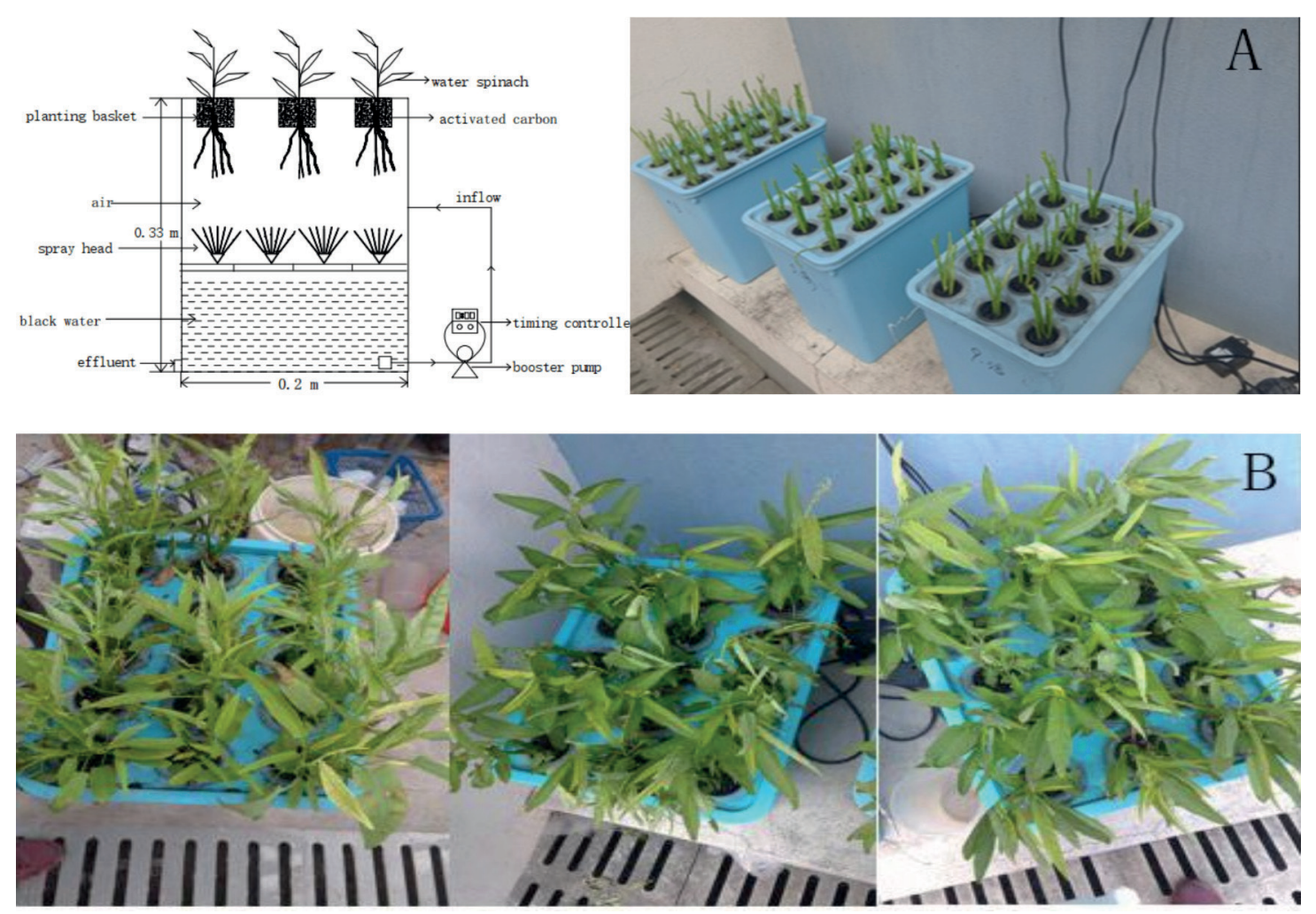

Fig. 1. Schematic diagram of the aeroponic cultivation devices and photography of the actual devices (A: initial-stage test; B: mid-stage test). 


\section{Results and Discussion}

Effect of the Run Time on the COD Removal Efficiency

Throughout the entire process, the COD removal rate of QW1 was significantly higher than that of QW2 and QW3, with a maximum of $98.54 \%$ (Fig. 2a). The removal rate of QW2 was higher than that of QW3, with a maximum of $88.07 \%$. The removal rate of QW3 was lower than that of QW1 and QW2, with a peak value of $81.97 \%$. During the 50 -day trial period, the influent COD concentration ranged from 183.00 to $237.00 \mathrm{mg} / \mathrm{L}$. After treatment for 24 hours, the concentrations in QW1, QW2, and QW3 varied from 3.00 to $30.00,24.00$ to 66.00 , and 33.00 to $95.00 \mathrm{mg} / \mathrm{L}$, respectively, with an average removal rate of $90.40 \%, 81.27 \%$, and $71.66 \%$, respectively. The removal in the three devices can be
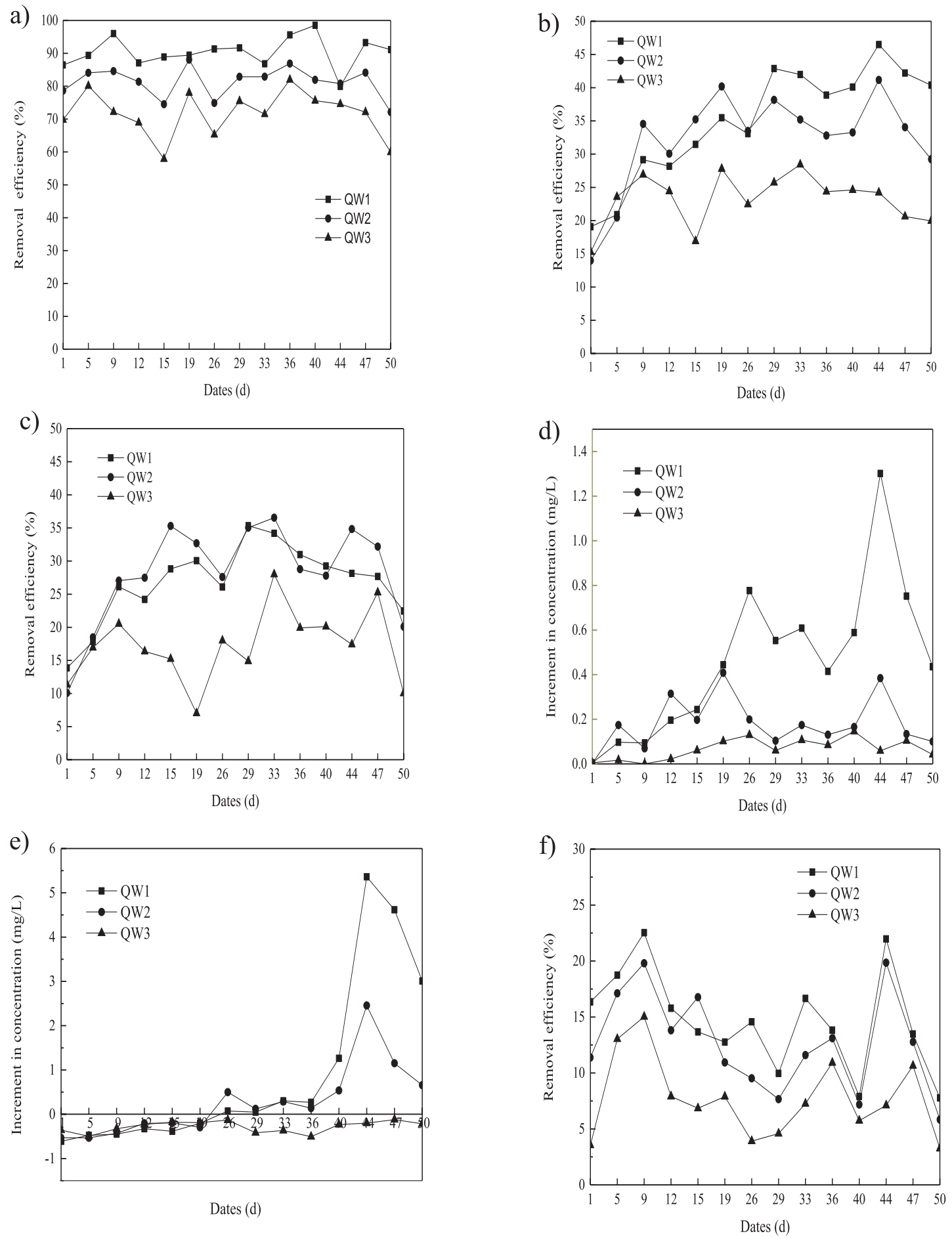

Fig. 2. Efficiency of the removal of $\mathrm{COD}$ a), $\mathrm{NH}_{4}^{+}-\mathrm{N} \mathrm{b}$ ), $\mathrm{TN}$ c), and $\mathrm{TP}$ f) and concentration variation of $\mathrm{NO}_{2}^{-}-\mathrm{N} \mathrm{d}^{-}$and $\mathrm{NO}_{3}^{-}-\mathrm{N} \mathrm{e}^{-}$in the aeroponic devices. 
divided into three stages, that is, small-scale fluctuation in the first period, slight increase in the middle period, and gradual decline in the later period. The removal rates of the three devices reached their maxima in the middle and later stages.

During the purification of wastewater by plants, the COD removal can be mainly attributed to the adsorption of the filler in the planting basket, degradation of the microbial membrane that formed on the surface of the filter media, self-sedimentation of organic pollutants, and absorption and degradation of plants during the growth progress [15]. The filler selected for this test was columnar activated carbon, which has a large specific surface area and high porosity. It does not only absorb organic substances from black water but also provides an excellent living environment for microorganisms to degrade pollutants. The activated carbon in the aeroponic system without plants approached adsorption saturation after a run time of approximately five days, with a COD removal of $51.00 \%$ (Table S3). In the early stage of the test, more than $50.00 \%$ of the COD was removed by the adsorption and interception of activated carbon because of the slow growth of the water spinach and incomplete development of the microbial community. Because the run interval was shorter, the contact between black water and air and activated carbon was increased, which was conducive to the formation of aerobic microbial communities and absorption of pollutants by activated carbon. Therefore, the COD removal rate of the three devices in the initial stage of the test was ranked as follows: QW1 $>\mathrm{QW} 2>\mathrm{QW} 3$. With the increase in the growth rate, the water spinach roots increasingly developed, as a vast living space for microorganisms and adsorbing more pollutants. Thus, the COD removal rate reached the maximum in the intermediate stage of the test, with an amount of growing activated sludge accumulated and the microbial community attached on plant roots formed gradually. In this case, the removal mainly depended on the assimilation of plants and degradation of microorganisms. At the end of the test, the growth of the water spinach almost stopped and the removal mainly depended on the complete microbial community. Therefore, the removal rates of the three devices showed small decreases in the later period of the test.

The synthetic black water was in contact with air in the form of droplets because of intermittent atomisation of the devices, which greatly promoted the mass transfer between gas and liquid. The DO content of the synthetic black water in QW1, QW2, and QW3 differs because of the different run times. The DO concentration in QW1, QW2, and QW3 varies from 4.52 to 7.35, 3.19 to 6.54 , and 0.82 to $4.30 \mathrm{mg} / \mathrm{L}$, respectively. The COD removal in the aeroponic system positively correlates with the DO variation. Thus, it can be concluded that the respiration of aerobic microorganisms plays a critical role in the removal of organic pollutants in the aeroponic system.

\section{Effect of the Run Time on the $\mathrm{NH}_{4}^{+}-\mathrm{N}$ Removal Efficiency}

In the first five days of the experiment, the removal of $\mathrm{NH}_{4}^{+}-\mathrm{N}$ in the three devices was similar (Fig. 2b). However, major differences were observed after the ninth day. From the $9^{\text {th }}$ to the $26^{\text {th }}$ day of the test, the removal rate of $\mathrm{NH}_{4}^{+}-\mathrm{N}$ in QW2 was higher than that in QW1 and QW3. However, after the $29^{\text {th }}$ day, the removal rate in QW1 started to significantly increase and eventually exceeded that of QW2. Starting on the $9^{\text {th }}$ day of the trial, the treatment performance of QW3 was worse than that of QW1 and QW2. During the whole test, the influent $\mathrm{NH}_{4}^{+}-\mathrm{N}$ concentration ranged from 29.57 to $34.01 \mathrm{mg} / \mathrm{L}$. After treatment for 24 hours, the $\mathrm{NH}_{4}^{+} \mathrm{-}$ concentration in QW1, QW2, and QW3 varied from 16.25 to $26.51,17.87$ to 28.18 , and 22.35 to $27.76 \mathrm{mg} / \mathrm{L}$, respectively. In QW1, the highest $\mathrm{NH}_{4}^{+}-\mathrm{N}$ removal rate was observed on the $44^{\text {th }}$ day, with a peak of $46.49 \%$. The removal rate of QW2 was highly variable and reached maxima on the $19^{\text {th }}$ and $44^{\text {th }}$ day, respectively, with peak values of $40.19 \%$ and $41.17 \%$, respectively. The removal rate of QW3 fluctuated in the early stage and then peaked on the $19^{\text {th }}$ and $33^{\text {rd }}$ day respectively, with a maximum of $28.43 \%$.

The removal of $\mathrm{NH}_{4}^{+}-\mathrm{N}$ in an aeroponic cultivation system possibly depends to the adsorption onto activated carbon and physical, chemical, and biological effects between the root system of water spinach and microorganisms. The adsorption of $\mathrm{NH}_{4}{ }^{+} \mathrm{N}$ onto activated carbon alone increased with increasing run time. A total of $45.00 \%$ of $\mathrm{NH}_{4}^{+}-\mathrm{N}$ was finally removed within 3 days (Table S3), which is basically consistent with the $\mathrm{NH}_{4}^{+}-\mathrm{N}$ removal in the initial stage of the experiment. Therefore the $\mathrm{NH}_{4}^{+}-\mathrm{N}$ of black water was mainly removed by the adsorption onto activated carbon in the initial stage. At this point, the formation of the microbial community was incomplete and thus had no effect on the removal. With increasing growth rate of the water spinach, the uptake of $\mathrm{NH}_{4}^{+}-\mathrm{N}$ began to increase. The higher removal efficiency in QW2 compared with QW1 in the first 26 days is due to the better growth status of the water spinach in QW2. At the same time, the nitrifying bacteria that grew on the surface of the activated carbon filler and among the roots of the water spinach and the activated sludge that formed at the bottom of the devices converted $\mathrm{NH}_{4}^{+}-\mathrm{N}$ into nitrate or nitrite nitrogen [16]. The nitrification process can be described with the following equation [17]:

$$
\begin{gathered}
\mathrm{NH}_{4}^{+}+1.5 \mathrm{O}_{2} \rightarrow \mathrm{NO}_{2}^{-}+\mathrm{H}_{2} \mathrm{O}+2 \mathrm{H}^{+} \\
\mathrm{NO}_{2}^{-}+0.5 \mathrm{O}_{2} \rightarrow \mathrm{NO}_{3}^{-}
\end{gathered}
$$

Therefore, using activated carbon as the filler enhances the microbial activity within the aeroponic system and promotes the absorption of rhizosphere microorganisms, root retention, and nitrification and 
denitrification around the rhizosphere, resulting in improved efficiency of the $\mathrm{NH}_{4}^{+}-\mathrm{N}$ removal.

In the middle and later stages of the experiment, microorganisms began to dominate. The interval of QW1 was shorter and thus the black water was more frequently exposed to air, which enhanced the DO concentration in the black water. As a result, the growth and reproduction of nitrifying bacteria were promoted and the $\mathrm{NH}_{4}^{+}-\mathrm{N}$ removal was accelerated.

The device QW3 was in an anoxic environment for a longer time. This was not conducive to the activity of aerobic nitrobacteria and resulted in a low $\mathrm{NH}_{4}^{+}-\mathrm{N}$ removal rate. Because the trial was carried out in winter, the low outdoor temperature $\left(\sim 15^{\circ} \mathrm{C} \pm 5^{\circ} \mathrm{C}\right)$ and the large temperature difference between day and night severely inhibited the activity of the nitrifying bacteria $[18,19]$. Therefore, the $\mathrm{NH}_{4}^{+}-\mathrm{N}$ removal efficiency of the three devices was overtly confined, ranging from $15.26 \%$ to $46.49 \%$.

\section{Effect of the Run Time on the TN Removal Efficiency}

During the whole experiment, the $\mathrm{TN}$ concentration of the influent varied from 30.89 to $36.54 \mathrm{mg} / \mathrm{L}$. After a run time of 24 hours, the TN concentration in QW1, QW2, and QW3 ranged from 21.33 to 27.92, 20.18 to 29.14 , and 24.06 to $32.19 \mathrm{mg} / \mathrm{L}$, respectively. The average TN removal rate in QW1, QW2, and QW3 was $26.79 \%, 28.14 \%$, and $17.21 \%$, respectively (Fig. 2 c).

During the whole test, the TN removal of QW1 was similar to that of QW2, but that of QW3 was worse than that of QW1 and QW2. The TN removal efficiency of the three devices significantly varied in the early stage of the trial and then gradually decreased in the end. The maximum removal rates in QW1 were obtained on the $9^{\text {th }}, 19^{\text {th }}$ and $29^{\text {th }}$ day, respectively. In QW2, it reached peaks on the $15^{\text {th }}, 33^{\text {rd }}$ and $44^{\text {th }}$ day, respectively. In QW3, the highest rates were achieved on the $9^{\text {th }}, 33^{\text {rd }}$ and $47^{\text {th }}$ day, respectively. The maximum TN removal occurred at different times in the three devices, which all exhibited fluctuations. This may be due to the sudden increase or decrease in temperature. Overall, the microbial activity is susceptible to changes in the temperature.

In the phytoremediation process, the nitrogen removal from sewage is due to the adsorption onto activated carbon filler, assimilation of plants, and nitrification or denitrification due to microbial organisms in the water and roots [20]. The plants had a smaller nitrogen demand because of the initially slow growth of the water spinach. The main removal of nitrogen in three devices mainly depended on the physical adsorption onto activated carbon such that the removal efficiency insignificantly changed. In the middle period of the test, it was necessary to absorb more inorganic nitrogen as nutrient for the synthesis of organic nitrogen, such as vegetable protein, because the water spinach thrived. At the same time, the aerobic-anoxic-anaerobic microenvironment formed near the roots of the water spinach, which was conducive to the coexistence of nitrifying and denitrifying bacteria. Thus, the efficiency of the nitrogen removal from sewage significantly improved due to the enhanced nitrification and denitrification [21]. In addition, the microorganisms in the activated sludge also removed parts of the nitrogen from the water by nitrification and denitrification.

Denitrification is a result the reduction of $\mathrm{NO}_{3}{ }^{-} \mathrm{N}$ to $\mathrm{N}_{2}$ or $\mathrm{N}_{2} \mathrm{O}$ by denitrifying bacteria under anaerobic conditions [17]. The reaction equation is as follows [22]:

$$
\mathrm{NO}_{3}^{-}+4 \mathrm{~g} \mathrm{COD}+\mathrm{H}^{+} \rightarrow 0.5 \mathrm{~N}_{2}+1.5 \mathrm{~g} \text { sludge }
$$

The spray interval time in QW3 was the longest such that the anaerobic reaction time was sufficient. However, the TN removal rate was the lowest because of the shorter aerobic reaction time, which was not conducive to the formation of $\mathrm{NO}_{3}^{-}-\mathrm{N}$. The devices QW1 and QW2 had an adequate aerobic reaction time but lacked an anaerobic reaction time. This may also explain the similar TN removal efficiency of QW1 and QW2. In the later period of the test, the growth of the water spinach most stopped, which resulted in a decreased nitrogen demand.

\section{Effect of the Run Time on the $\mathrm{NO}_{2}^{-}-\mathrm{N}$ Removal Efficiency}

Throughout the whole experiment, the concentration of $\mathrm{NO}_{2}^{-}-\mathrm{N}$ in the three devices was higher than the influent concentration (Fig. 2d). In other words, the reduction of $\mathrm{NO}_{2}^{-}-\mathrm{N}$ was lower than the production during the experiment. The increase in the concentrations of QW1 and QW2 in the early stage was similar and the concentrations were higher than that of QW3. Later, the concentration in QW1 was significantly higher than that of QW2 and QW3. During the entire experiment, the influent $\mathrm{NO}_{2}^{-}-\mathrm{N}$ concentration was negligible. After treatment for 24 hours, the $\mathrm{NO}_{2}^{-}-\mathrm{N}$ concentration in QW1, QW2, and QW3 varied from 0.005 to $1.302,0.002$ to 0.416 , and 0.005 to $0.147 \mathrm{mg} / \mathrm{L}$, respectively. The peak values of the $\mathrm{NO}_{2}^{-}-\mathrm{N}$ concentration in QW1 were observed on the $26^{\text {th }}$ and $44^{\text {th }}$ day, respectively, which roughly corresponded to the time with the lowest $\mathrm{TN}$ and highest $\mathrm{NH}_{4}{ }^{+} \mathrm{N}$ removal rates. The $\mathrm{NO}_{2}^{-}-\mathrm{N}$ concentration in QW2 first increased and then remained constant. In QW3, it imperceptibly increased in the early period and then remained low.

The $\mathrm{NO}_{2}^{-}-\mathrm{N}$ produced in the three devices is mostly due to the nitrification of $\mathrm{NH}_{4}^{+}-\mathrm{N}$. Under aerobic conditions, the nitrification process can be mainly divided into two stages. In the first stage, ammonia oxidation bacteria (AOB) oxidise ammonia nitrogen to nitrite $\left(\mathrm{NO}_{2}^{-}\right)$catalysed by ammonia monooxygenase (AMO) and hydroxylamine oxidoreductase (HAO). In the second stage, nitrite oxidising bacteria (NOB) oxidise $\mathrm{NO}_{2}^{-}$to $\mathrm{NO}_{3}^{-}$[23]. The concentrations of 
the two most significant microorganisms in the nitrification process, $\mathrm{AOB}$ and $\mathrm{NOB}$, are limited at low temperatures $\left(\leq 15^{\circ} \mathrm{C}\right)[24,25]$, leading to the accumulation of $\mathrm{NO}_{2}^{-}-\mathrm{N}$ in the later stage of $\mathrm{QW1}$, which is consistent with the accumulation of $\mathrm{NO}_{2}^{-} \mathrm{-N}$ at $12^{\circ} \mathrm{C}-14^{\circ} \mathrm{C}$ reported by Yuan and Peng [26]. Similarly, the $\mathrm{NO}_{2}^{-}-\mathrm{N}$ concentration in QW2 was higher than that in QW3. The reason for the great fluctuation may be a distinct temperature change, which has a significant impact on the activity of nitrifying bacteria. The elevated temperature promoted the nitrification reaction, especially in the later period.

\section{Effect of the Run Time on the $\mathrm{NO}_{3}^{-}-\mathrm{N}$ Removal Efficiency}

Throughout the test, the influent $\mathrm{NO}_{3}^{-}-\mathrm{N}$ concentration ranged from 0.48 to $0.86 \mathrm{mg} / \mathrm{L}$ (Fig. 2e). After treatment for 24 hours, the $\mathrm{NO}_{3}^{-}-\mathrm{N}$ concentration in QW1, QW2, and QW3 varied from 0.07 to 6.09, 0.09 to 3.18 , and 0.12 to $0.62 \mathrm{mg} / \mathrm{L}$, respectively. As shown in Fig. 2e, the $\mathrm{NO}_{3}^{-}-\mathrm{N}$ content in QW1 and QW2 began to increase on the $26^{\text {th }}$ day and reached the maximum on the $44^{\text {th }}$ day. The maximum concentration was 5.36 and $2.46 \mathrm{mg} / \mathrm{L}$, respectively. However, the $\mathrm{NO}_{3}^{-}-\mathrm{N}$ content of QW3 was always lower than that of raw water and the average removal rate was $44.03 \%$. The $\mathrm{NO}_{2}^{-}-\mathrm{N}$ and $\mathrm{NO}_{3}^{-}-\mathrm{N}$ concentrations in the three devices first increased and then decreased during the experiment. The devices QW1 and QW2 both reached peaks on the $44^{\text {th }}$ day, probably because of the simultaneous occurrence of the two nitrification stages.

Nitrogen absorbed by plants mainly involves nitrate nitrogen and ammonia nitrogen of water as well as urea and amino acids, which can be converted into parts of their tissues through assimilation [27, 28]. In the initial stage of the test, the water spinach thrived; thus, the $\mathrm{NO}_{3}^{-}-\mathrm{N}$ demanded was greater. At the same time, the removal $\mathrm{NO}_{3}^{-}-\mathrm{N}$ from black water was better due to the adsorption onto activated carbon. Based on Fig. 2e), it can be concluded that the vigorous growth period of water spinach lasted 26 days, which is similar to the research results of $\mathrm{Li}$ et al. [29]. After the $26^{\text {th }}$ day, the water spinach entered a declining phase and the absorption of nitrogen decreased.

Moreover, $\mathrm{NH}_{4}^{+}-\mathrm{N}$ entered plant cells in an active process, while $\mathrm{NO}_{3}^{-}-\mathrm{N}$ passively entered the cells; therefore, the absorption of $\mathrm{NO}_{3}^{-}-\mathrm{N}$ stopped in the end of this study [30]. At this time, the $\mathrm{NO}_{3}^{-}-\mathrm{N}$ removal in the three devices mainly depended on the denitrification by denitrifying bacteria. However, the run time interval of QW1 and QW2 was smaller than that of QW3, leading to a shorter anaerobic reaction, which was not conducive to denitrificatio. In summary, $\mathrm{NO}_{3}^{-}-\mathrm{N}$ began to accumulate, and the accumulated concentration in QW1 was higher than that in QW2. A better $\mathrm{NO}_{3}^{-} \mathrm{N}$ removal was achieved in QW3 because the anaerobic reaction time was long enough. In the later stage of the test, the $\mathrm{NO}_{3}-\mathrm{N}$ concentration in QW1 and QW2 decreased, possibly because the increased temperature promoted the nitrification and denitrification.

\section{Effect of the Run Time on the TP Removal Efficiency}

During the experiment, the concentration of influent TP varied from 13.57 to $19.59 \mathrm{mg} / \mathrm{L}$. After treatment for 24 hours, the TP concentration in QW1, QW2, and QW3 varied from 11.36 to $16.74,11.67$ to 17.73 , and 12.54 to $18.82 \mathrm{mg} / \mathrm{L}$, respectively. The TP removal efficiency of QW1 and QW2 lightly differed during the entire test (Fig. 2f). The removal efficiency of QW3 was lower and the average removal rate of TP for QW1, QW2, and QW3 was $14.71 \%, 12.66 \%$, and 7.69\%, respectively.

The phosphorus could be removed from the black water by the absorption by the water spinach and adsorption onto activated carbon. Because of the formation of activated sludge at the bottoms of the devices and alternating anaerobic and aerobic operating conditions, parts of the phosphorus could be removed from the black water by phosphorus release and excessive phosphorus uptake processes. Because QW3 had the longest run time interval, the device was exposed to an anaerobic environment for a longer time such that the phosphorus absorbed by activated sludge under aerobic conditions was released. This may explain that the TP removal of QW3 is the worst. The run time intervals of QW1 and QW2 were shorter and such the exposure time of the activated sludge to anaerobic conditions was shorter. Phosphorus could be removed with the discharge of the activated sludge. However, most of the activated sludge must be retained in the devices to ensure the efficient removal of other pollutants. Therefore, the TP removal rate in the three devices began to decrease after the ninth day. The phosphorus removal in the end of the test possibly increased because the increase in the temperature promoted the phosphorus uptake by phosphateaccumulating organisms [31-34].

\section{Difference Analysis of Different Models}

Based on the test results obtained for the black water treatment, the removal rates of the water quality indicators (e.g. $\mathrm{NH}_{4}^{+}-\mathrm{N}, \mathrm{TN}, \mathrm{TP}, \mathrm{COD}, \mathrm{NO}_{3}^{-}$ $-\mathrm{N}$, and $\mathrm{NO}_{2}^{-}-\mathrm{N}$ ) were used to analyse the different experimental treatments (Table 2). The efficiency of the $\mathrm{NH}_{4}^{+}-\mathrm{N}$ removal in QW3 was markedly different from that of QW1 or QW2, while the efficiencies of the TN, TP, and COD removals of QW1, QW2, and QW3 significantly differed. The increase in the $\mathrm{NO}_{3}^{-}-\mathrm{N}$ and $\mathrm{NO}_{2}^{-}-\mathrm{N}$ concentrations in QW1, QW2, and QW3 noticeably differed. With respect to nitrification and denitrification, the DO concentration in the black water significantly affects the transformation of $\mathrm{N}$ including $\mathrm{NH}_{4}^{+}-\mathrm{N}, \mathrm{NO}_{2}^{-}-\mathrm{N}$, and $\mathrm{NO}_{3}^{-}-\mathrm{N}$. The notable difference of the $\mathrm{NH}_{4}^{+}-\mathrm{N}, \mathrm{NO}_{2}^{-}-\mathrm{N}$, and $\mathrm{NO}_{3}^{-}-\mathrm{N}$ 
Table 2. F test analysis

\begin{tabular}{|c|c|c|c|c|}
\hline Detection indicators & Samples & $\mathrm{F}$ & $\mathrm{P}$ & Significant difference \\
\hline $\mathrm{NH}_{4}^{+}-\mathrm{N}$ & QW1QW2 & 1.319 & 0.312 & \\
\hline Removal & QW1QW3 & 4.687 & 0.005 & $*$ \\
\hline Rate & QW2QW3 & 3.553 & 0.015 & $*$ \\
\hline $\mathrm{TN}$ & QW1QW2 & 0.600 & 0.184 & \\
\hline Removal & QW1QW3 & 1.083 & 0.444 & \\
\hline Rate & QW2QW3 & 1.806 & 0.150 & \\
\hline TP & QW1QW2 & 1.015 & 0.489 & \\
\hline Removal & QW1QW3 & 1.567 & 0.215 & \\
\hline Rate & QW2QW3 & 1.543 & 0.222 & \\
\hline COD & QW1QW2 & 1.011 & 0.493 & \\
\hline Removal & QW1QW3 & 0.456 & 0.085 & \\
\hline Rate & QW2QW3 & 0.451 & 0.082 & \\
\hline $\mathrm{NO}_{3}^{-}-\mathrm{N}$ & QW1QW2 & 6.045 & 0.000 & $*$ \\
\hline Increment & QW1QW3 & 236.092 & 0.000 & $*$ \\
\hline In concentration & QW2QW3 & 39.054 & 0.000 & $*$ \\
\hline $\mathrm{NO}_{2}^{-}-\mathrm{N}$ & QW1QW2 & 8.832 & 0.000 & $*$ \\
\hline Increment & QW1QW3 & 54.346 & 0.000 & $*$ \\
\hline In concentration & QW2QW3 & 6.153 & 0.001 & $*$ \\
\hline
\end{tabular}

( $\mathrm{P} \leq 0.05$ is considered to be the significant difference)

concentrations in the three devices can be ascribed to their different reoxygenation capacities. The $\mathrm{TN}$ and TP removal was not notable among the three devices. However, the $\mathrm{NH}_{4}^{+}-\mathrm{N}$ removal in QW1 and QW3, QW2 and QW3 notably differed.

\section{Analysis of the Water Spinach Growth under Low Temperature}

After an operation for more than two months, the dry weight of the water spinach in three devices, that is, QW1, QW2, and QW3, was 13.50, 21.50 and 20.00 g, respectively. The device QW1 exhibited the lowest biomass because it had the shortest spraying interval and the roots were exposed to low temperature for a longer time, resulting in the withering of the water spinach in the later stage. The devices QW2 and QW3 had a longer interval and thus the adverse effect of the low temperature on the water spinach growth was smaller. Therefore, the growth status in both QW2 and QW3 was better than that in QW1.

\section{Conclusions}

(1) The efficiencies of the $\mathrm{COD}, \mathrm{NH}_{4}^{+}-\mathrm{N}$, and TP removals in the three devices were ranked as follows:
QW1 $>$ QW2 $>$ QW3. The average removal rates were $90.40 \%, 35.02 \%$, and $14.71 \%$ in QW1; $81.27 \%, 32.27 \%$, and $12.66 \%$ in QW2; and $71.66 \%, 23.23 \%$, and $7.69 \%$ in QW3; respectively.

The TN removal efficiencies of the three devices have the following order: QW1 $\approx \mathrm{QW} 2>\mathrm{QW} 3$. The average TN removal rates were $26.79 \%, 28.14 \%$, and $17.21 \%$, respectively.

(2) The $\mathrm{NO}_{2}^{-}-\mathrm{N}$ content in QW1, QW2, and QW3 increased, with $\mathrm{QW} 1>\mathrm{QW} 2>\mathrm{QW} 3$, and the average content was $0.465,0.183$, and $0.067 \mathrm{mg} / \mathrm{L}$, respectively. The nitrate removal rate of QW1 and QW2 gradually decreased with the increase of running time, and finally showed an increasing state, and the decrease and increase rate of QW1 was higher than QW2. However, the nitrate of QW3 was reduced throughout the whole experiment.

(3) The $\mathrm{NH}_{4}^{+}-\mathrm{N}$ removals in QW1QW3 and QW2QW3 significantly differed. The removals of TN, TP, and COD in QW1, QW2, and QW3 were similar. The increase in the concentrations of $\mathrm{NO}_{3}^{-}-\mathrm{N}$ and $\mathrm{NO}_{2}{ }^{-} \mathrm{N}$ concentrations in QW1QW2, QW1QW3, and QW2QW3 also significantly differed.

(4) The dry weights of the water spinach in QW1, QW2, and QW3 after a run of more than two months were $13.50,21.50$, and $20.00 \mathrm{~g}$, respectively. The inhibition of the growth of the water spinach was 
stronger in QW1 than that in QW2 and QW3.

\section{Acknowledgements}

This work was supported by the National Science and Technology Major Project (No. 2013ZX0731200101), Major Project of Science and Technology in Zhejiang Province (No. 2015C03016), National Natural Science Foundation of China (Grant No. 51808406) and Wenzhou Science and Technology Innovation Project in the Control of the Contaminated Water (No. W2017004).

\section{Conflict of Interest}

The authors declare no conflict of interest.

\section{References}

1. JIANG S.G. China's water pollution status and prevention countermeasures. Aquatic Science and Technology Information 37 (4), 177, 2010.

2. LI Y.R. Purifying effects and rules research on river water in Suzhou ancient district by plant floating-bed technology. Nanjing: Hohai University. 2006.

3. MRNG Z. Research on relevant problems of wastewater reuse. China Hi-Tech Enterprises 08, 77, 2016.

4. ENGIN G.O., DEMIR I. Cost analysis of alternative methods for wastewater handling in small communities. Journal of Environmental Management 79, 357, 2006.

5. FAN Y.B., LI G. Treatment and reuse of toilet wastewater by an airlift external circulation membrane bioreactor. Process Biochemistry 41, 1364, 2006.

6. LV X.W., SONG, H.L. Study on the removal characters of nitrogen and phosphorus in eutrophicated stream water by aquatic vegetables. Jiangsu Environmental Science and Technology 02, 1, 2004.

7. YANG X.L., GUO J.Y. A study on purification of eutrophic aquaculture water by ipomoea aqutica. Crop Magazine 01, 49, 2012.

8. YOU W.H., LIU S.Y., QIAN X.Y. A study on polluted water body purification with economical aquatic plants. Journal of East China Normal University (Natural Science Edition) 01, 99, 2000.

9. ZHOU X.P., WANG J.G., XUE L.H., XU X.F., YANG L.Z. $\mathrm{N}$ and $\mathrm{P}$ removal characters of eutrophic water body under planted float. Journal of Applied Ecology 11, 195, 2005.

10. ZHOU Z.M., CHEN C.Y., YE Q., ZHAO Z.L. Study on the purification effects of eutrophic water body in floatingbed plant systems. Journal of Huaqiao University (Natural Science Edition) 31 (05), 576, 2010.

11. ZHANG J.G., HE C.M., LING M., WANG H.F. Review on the application and research progress of aeroponic cultivation. Forestry and Environmental Science 33 (04), 130, 2017.

12. YANG Y.J., LIU S., ZHANG W.L. Experiment of toiletflushing sewage treatment process for reuse of recirculated flushing water. Water purification technology 36 (09), 69, 2017.

13. YAN Z.M., MA W., XU G., LI Z.W., ZHENG X.Y., KONG H.N. Technology of aerosol cultivation for nitrogen and phosphorus removal in toilet flushing wastewater treatment. Water Purification Technology 36 (02), 83, 2017.

14. XU H., FAN Y. Treatment of wastewater from a toilet for reclamation with an airlift external recirculated membrane bioreactor. Chinese Journal of Environmental Science 24 (2), 125, 2003.

15. ZHU J.P., CHENG K., SONG B.Z. Analysis of correlation between microbe quantity and purification effect of hydroponics chlorophytum comosum wastewater purification system. Technology of Water Treatment 35 (6), 14, 2009.

16. WANG W., DING Y., WANG Y.H., SONG X.S. The application and research progress of wetland plants in the nitrogen removal of constructed wetlands. Technology of Water Treatment 40 (3), 22, 2014.

17. GISVOLD B., ODEAARD H., FOLLESDAL M. Enhancing the removal of ammonia in nitrifying biofilters by the use of a zeolite containing expanded clay aggregate filtermedia. Water Science \& Technology 41 (9), $107,2000$.

18. LIU H., PENG Y.Z., LU J.Y., LI H., NAN Y.B., WANG J., CHEN Y.Z. Effects of temperature on shortcut nitrification and nitrification activity of nitrification in an intermittent aeration sequencing batch reactor. Environmental Science 38 (11), 4656, 2017.

19. TAN J., DONG B., DAI X.H. Influence of temperature on nitrification characteristics and nitrifying bacteria community in integrated fixed film-activated sludge process. Water Purification Technology 35 (02), 21, 2016.

20. WU H.M. Cyclic processes of carbon, nitrogen and phosphorus in constructed wetlands and its environmental effects. Jinan: Shandong University. 2014.

21. LIU J., LIU Y.L., YE Q.F., WANG H.Y. Study on the removal of nitrogen, phosphorus and inhibiting effect of algae growth by aquatic plants. Journal of Nuclear Agricultural Sciences 21 (4), 393, 2007.

22. HENZE M., VAN LOOSDRECHT M.C.M., EKAMA G.A., BRDJANOVIC D. Biological wastewater treatment: principles, modelling and design. London: IWA. 2008.

23. YUAN J.J. Operation characteristics and pollutants removal mechanism of vegetation-activated sludge process treating domestic wastewater. Harbin Institute of Technology. 2017.

24. CUI D., LI A., QIU T., CAI R., PANG C.L., WANG J.H., YAN J.X., MA F., REN N.Q. Improvement of nitrification efficiency by bioaugmentation in sequencing batch reactors at low temperature. Frontiers of Environmental Science \& Engineering 8 (6), 937, 2014.

25. D'ANTEO S., MANNUCCI A., MELIANI M., VEMI F., PETRONI G., MUNZ G., LUBELlO C., MORI G., VANNINI C. Nitrifying biomass characterization and monitoring during bioaugmentation in a membrane bioreactor. Environmental Technology 36 (24), 1, 2015.

26. YUAN L.J., PENG D.C. Short-cut nitrificationdenitrification biological denitrification. China Water and Wastewater 16 (2), 29, 2000.

27. SCHULTZ R.E., BOUCHARD V.L., FREY S.D. Over yielding and the role of complementary use of nitrogen in wetland plant communities. Aquatic Botany 97 (1), 1, 2012.

28. WANG Q.J., ZHU P., SONG J.J., ZOU G.L. Combined process of constructed wetlands in the application of the polluted water treatment. Technology of Water Treatment 39 (2), 16, 2013.

29. LI J., LV T., HUA J.H. Growth features of Ipomoea aquatica Forsk. Planted on artificial floating beds and its 
application in aquaculture wastewater purification. Journal of Natural Science of Hunan Normal University 37 (02), 22,2014

30. ZHOU X.H., WANG G.X., YANG F. Characteristics of growth, nutrient uptake, purification effect of Ipomoea aquatica, Lolium multiflorum, and Sorghum sudanense grown under different nitrogrn levels. Desalination 273 (2-3), 366, 2011.

31. YANG L.F. Effect and mechanisms of iron plaque on root surface on phosphorus removal of wetland plant. Sichuan Agriculture University. 2011.
32. ZHOU Y.M. Phosphorus removal enhancement in main treatment processing technologies of rural domestic sewage. Zhejiang University. 2019.

33. MC CLINTOCK S.A., RANDALL C.W., PATTARKINE V.M. Effects of temperature and mean cell residence time on biological nutrient removal processes. Water Environment Research 65 (5), 110, 1993.

34. CONVERTI A., ROVATTIM., DEL BORGHI M. Biological removal of phosphorus from wastewaters by alternating aerobic and anaerobic conditions. Water Research 29 (1), 263, 1995. 


\section{Supplementary Material}

\section{Synthetic Black Water Treatment by Aeroponic Cultivation of Water Spinach: Effect of the Pump Run Time}

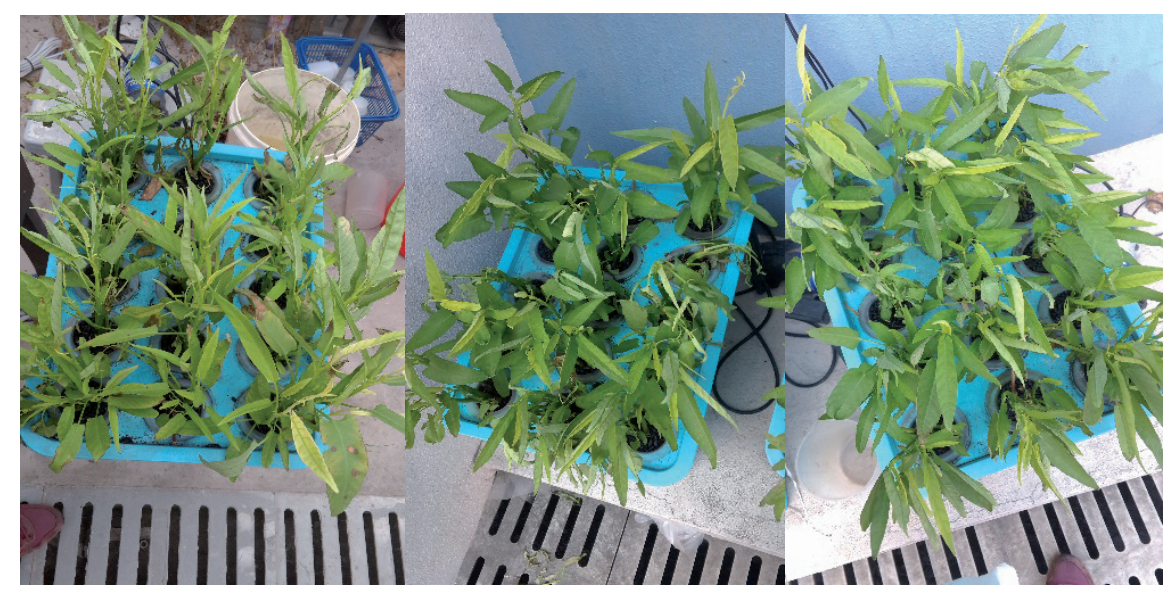

Fig. S1. The actual devices of aeroponic cultivation (the vegetation with leaves).

Table S1. Ingredients of simulated black water (30 L).

\begin{tabular}{|c|c|c|c|}
\hline Reagents & Dosing amount & Index & Concentration (mg/L) \\
\hline $\mathrm{C}_{6} \mathrm{H}_{12} \mathrm{O}_{6}$ & $6 \mathrm{~g}$ & $\mathrm{COD}$ & 200.00 \\
\hline $\mathrm{NH}_{4} \mathrm{Cl}$ & $2.75 \mathrm{~g}$ & $\mathrm{NH}_{4}^{+}-\mathrm{N}$ & 18.20 \\
\hline $\mathrm{KH}_{2} \mathrm{PO}_{4}$ & $2.4 \mathrm{~g}$ & $\mathrm{TP}$ & 32.00 \\
\hline $\mathrm{MgSO}_{4}$ & $1.2 \mathrm{~g}$ & $\mathrm{SO}_{4}^{2-}$ & 10.80 \\
\hline $\mathrm{CaCl}_{2}$ & $0.9 \mathrm{~g}$ & $\mathrm{Ca}^{2+}$ & - \\
\hline Trace element solution & $30 \mathrm{ml}$ & - & \\
\hline
\end{tabular}

Table S2. Ingredients of simulated black water.

\begin{tabular}{|c|c|c|}
\hline Element & Reagent & Dosing amount $(\mathrm{g} / \mathrm{L})$ \\
\hline $\mathrm{Fe}$ & $\mathrm{FeSO}_{4} \cdot 7 \mathrm{H}_{2} \mathrm{O}$ & 1.54 \\
\hline $\mathrm{B}$ & $\mathrm{H}_{3} \mathrm{BO}_{3}$ & 0.15 \\
\hline $\mathrm{Co}$ & $\mathrm{Co}\left(\mathrm{NO}_{3}\right)_{2} \cdot 6 \mathrm{H}_{2} \mathrm{O}$ & 0.183 \\
\hline $\mathrm{Zn}$ & $\mathrm{ZnCl}_{2}$ & 0.102 \\
\hline $\mathrm{I}$ & $\mathrm{KI}$ & 0.03 \\
\hline $\mathrm{Mn}$ & $\mathrm{MnSO}_{4} \cdot \mathrm{H}_{2} \mathrm{O}$ & 0.013 \\
\hline $\mathrm{Mo}$ & $\mathrm{Na}_{2} \mathrm{MoO}_{4} \cdot 2 \mathrm{H}_{2} \mathrm{O}$ & 0.06 \\
\hline $\mathrm{Cu}$ & $\mathrm{CuSO}_{4} \cdot 5 \mathrm{H}_{2} \mathrm{O}$ & 0.03 \\
\hline
\end{tabular}

Table S3. The removal of COD and $\mathrm{NH}_{4}^{+}-\mathrm{N}$ by the absorption of activated carbon in aeroponicsystem without water spinach.

\begin{tabular}{|c|c|c|}
\hline Time (d) & $\begin{array}{c}\text { COD removal rate } \\
(\%)\end{array}$ & $\begin{array}{c}\mathrm{NH}_{4}^{+}-\mathrm{N} \text { removal rate } \\
(\%)\end{array}$ \\
\hline 1 & 26.8 & 38.5 \\
\hline 3 & 41.1 & 45.1 \\
\hline 5 & 51.2 & 47.2 \\
\hline 9 & 55.2 & - \\
\hline
\end{tabular}


